frequency in the general population. Neurology 2016; 87:282-288.

2. Squitieri F, Jankovic J. Huntington's disease: how intermediate are intermediate repeat lengths? Mov Disord 2012;27: $1714-1717$.

3. Ha AD, Beck CA, Jankovic J. Intermediate CAG repeats in Huntington's disease: analysis of COHORT. Tremor Other Hyperkinet Mov 2012;2.
4. Cubo E, Ramos-Arroyo MA, Martinez-Horta S, et al. Clinical manifestations of intermediate allele carriers in Huntington disease. Neurology 2016;87:571-578.

5. Semaka A, Warby S, Leavitt BR, Hayden MR. Re: Autopsyproven Huntington's disease with 29 trinucleotide repeats. Mov Disord 2008;23:1794-1795.

(C) 2017 American Academy of Neurology

\title{
CORRECTIONS
}

\section{Tilt-induced vasovagal syncope and psychogenic pseudosyncope: Overlapping clinical entities}

In the article "Tilt-induced vasovagal syncope and psychogenic pseudosyncope: Overlapping clinical entities" by H. Blad et al., ${ }^{1}$ there is one error in the risk calculation of having both conditions (VVS and PPS) in our sample of 1164 tilt table tests, as the 23 mixed VVS/PPS episodes were not included. The actual VVS proportion should have read $14 \%(\mathrm{n}=143+23)$ rather than $12 \%(\mathrm{n}=143)$ and the actual PPS proportion should have read $6 \%(\mathrm{n}=51+23)$ rather than $5 \%(\mathrm{n}=51)$. VVS and PPS would therefore be expected to co-occur in 11 tilt-table tests $(0.14 \times 0.06 \times 1,164)$ rather than $7 / 1,164$ tilt-table tests. The coincidence of VVS and PPS still remains more frequent than chance would predict ( $23 \mathrm{vs} 11 ; p<0.001)$, and the error does not change the reported $p$ value or overall conclusion of the paper. The authors regret the error.

\section{REFERENCE}

1. Blad H, Lamberts RJ, van Dijk JG, Thijs RD. Tilt-induced vasovagal syncope and psychogenic pseudosyncope: Overlapping clinical entities. Neurology 2015;85:2006-2010.

\section{Cathepsin A-related arteriopathy with strokes and leukoencephalopathy (CARASAL)}

In the article "Cathepsin A-related arteriopathy with strokes and leukoencephalopathy (CARASAL)" by M. Bugiani et al.," there is an error in table 1. The mutation "c.922C $>\mathrm{T}$, Arg308Cys" in the penultimate row of the table should read "c.973C $>$ T, Arg325Cys," as consistently used in the main text of the paper. The authors regret the error.

\section{REFERENCE}

1. Bugiani M, Kevelam SH, Bakels HS, et al. Cathepsin A-related arteriopathy with strokes and leukoencephalopathy (CARASAL). Neurology 2016;87:1777-1786. 


\section{Neurology}

\section{Cathepsin A-related arteriopathy with strokes and leukoencephalopathy (CARASAL) Neurology 2017;88;335 \\ DOI 10.1212/WNL.0000000000003551}

\section{This information is current as of January 16, 2017}

Updated Information \& Services

References

Permissions \& Licensing

Reprints including high resolution figures, can be found at: http://n.neurology.org/content/88/3/335.2.full

This article cites 1 articles, 1 of which you can access for free at: http://n.neurology.org/content/88/3/335.2.full\#ref-list-1

Information about reproducing this article in parts (figures,tables) or in its entirety can be found online at:

http://www.neurology.org/about/about_the_journal\#permissions

Information about ordering reprints can be found online:

http://n.neurology.org/subscribers/advertise

Neurology ${ }^{\circledR}$ is the official journal of the American Academy of Neurology. Published continuously since 1951 , it is now a weekly with 48 issues per year. Copyright @ 2016 American Academy of Neurology. All rights reserved. Print ISSN: 0028-3878. Online ISSN: 1526-632X.

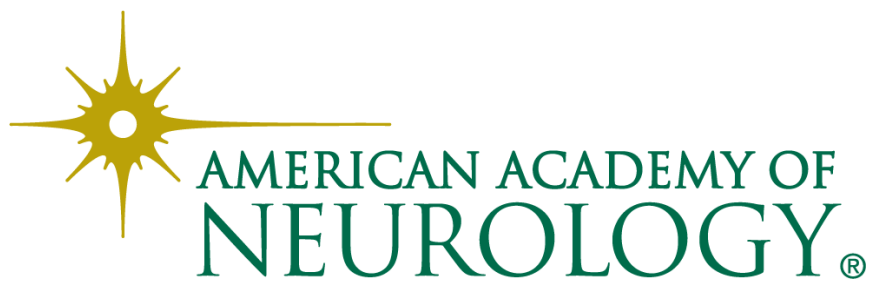

